\title{
ROADMAP PENGEMBANGAN PENANAMAN MODAL WILAYAH GARUT SELATAN KABUPATEN GARUT
}

\author{
M. Widaningsih \\ Universitas Garut, Fakultas Ekonomi \\ widamalizal@yahoo.com
}

\begin{abstract}
Abstrak. Keberhasilan pembangunan dalam kerangka otonomi daerah tidak terlepas dari keberhasilan daerah tersebut dalam melaksanakan pembangunan ekonomi daerah. Pembangunan ekonomi daerah harus melibatkan para pelaku pembangunan, Pemerintah daerah tidak bisa sendirian dalam melakukan proses pembangunan karena pemerintah daerah memiliki berbagai keterbatasan baik sumber daya manusia maupun anggaran. Oleh karena itu, diperlukan keterlibatan pihak lain, dalam hal ini adalah pihak Swasta atau penanam modal.Pemerintah daerah hanya bertanggung jawab secara lebih penuh dalam bentuk kebijakan dasar yang diperlukan bagi pembangunan daerah, salah satunya berupa kebijakan dasar pengembangan penanaman modal. Kabupaten Garut memiliki potensi daerah yang sangat banyak dan bervariasi. Kekayaan alamnya meliputi gunung, rimba, laut, pantai, sungai, bahan tambang, tanah yang subur dan panorama yang sangat indah. Potensi ini, jika dikelola dengan baik akan menjadi faktor pendorong yang sangat besar bagi percepatan pembangunan daerah.

Permasalahan yang akan menjadi topik perhatian pada kajian ini adalah masalah bidang usaha unggulan berupa potensi dan peluang investasi yang akan ditawarkan kepada investor. Saat ini informasi mengenai bidang usaha unggulan tersebut belum tersedia sesuai dengan kebutuhan.

Manfaat dalam kajian ini adalah: Memperoleh gambaran potensi ekonomi berupa komoditas/produk yang ada di Kabupaten Garut. Memperoleh gambaran produk unggulan dan potensi/peluang investasi terpilih di Kabupaten Garut.

Desain penelitian yang dipergunakan dalam kajian ini adalah descriptive analysis. Desain ini bertujuan untuk memperoleh gambaran tentang gejala-gejala yang diteliti pada saat sekarang. Dari hasil gambaran tersebut, selanjutnya dicari jawaban bagi pemecahan masalah atau fenomenafenomena yang ada.

Hasil dari penelitian ini adalah biasa mengidentifikasi potensi unggulan untuk dilakukan sebuah investasi dari berbagai sektor wilayah Garut selatan Kabupaten Garut.
\end{abstract}

Kata Kunci : Investasi, Potensi Unggulan

Abstract. The success of development within the framework of regional autonomy can not be separated from the success of the region in implementing regional economic development. Regional economic development must involve development actors, local governments can not be alone in the development process because local governments have various limitations both human and budgetary resources. Therefore, it requires the involvement of other parties, in this case the private sector or investors. Local government is only responsible more fully in the form of basic policies needed for regional development, one of which is the basic policy of investment development. Garut Regency has the potential of a very large and varied areas. Its natural wealth includes mountains, the jungle, the sea, the coast, rivers, minerals, fertile soil and beautiful panoramas. This potential, if managed properly will be a huge driving factor for the acceleration of regional development.

The problem that will be the topic of attention in this study is the issue of the leading business field of potential and investment opportunities that will be offered to investors. Currently, information about the leading business areas is not available as required.

Benefits in this study are: Gain a picture of economic potential in the form of commodities / products that exist in Garut regency. Obtained a picture of superior products and potential / investment opportunities selected in Garut regency. 
The research design used in this study is descriptive analysis. This design aims to obtain a description of the symptoms studied in the present moment. From the results of the picture, then sought answers to solving problems or phenomena that exist.

The result of this research is usually to identify the superior potential to be done an investment from various sectors Garut region south of Garut regency.

Keywords: Investment, Potential

\section{PENDAHULUAN}

Pembangunan daerah menjadi sangat berarti bagi perkembangan daerah ketika pemerintah melaksanakan otonomi daerah yang ditindaklanjuti dengan Undang-Undang Nomor 22 Tahun 1999 tentang Pemerintahan Daerah jo Undang-Undang Nomor 32 Tahun 2004 tentang Pemerintahan Daerah jo UndangUndang Nomor 23 Tahun 2014 tentang Pemerintahan Daerah. Kebijakan tersebut merupakan suatu keputusan besar yang membawa perubahan fundamental dalam tata kelola hubungan antara pemerintah pusat dan daerah, karena terjadinya pelimpahan kewenangan dan pembiayaan yang selama ini merupakan tanggung jawab Pemerintah Pusat. Pemberlakuan Undang-Undang tersebut menuntut pemerintah daerah untuk melaksanakan desentralisasi dan memacu pembangunan ekonomi guna peningkatan kesejahteraan masyarakat dan meningkatkan kemandirian daerah. Daerah harus mampu menggali, mengolah, mengelola dan memanfaatkan berbagai sumber daya dan hasil kekayaan alam, serta potensi ekonomi yang ada untuk meningkatkan taraf hidup dan kesejahteraan masyarakat serta peningkatkan pendapatan asli daerah untuk pembiayaan pembangunan.

Keberhasilan pembangunan dalam kerangka otonomi daerah tidak terlepas dari keberhasilan daerah tersebut dalam melaksanakan pembangunan ekonomi daerah. Pembangunan ekonomi daerah harus melibatkan para pelaku pembangunan, Pemerintah daerah tidak bisa sendirian dalam melakukan proses pembangunan karena pemerintah daerah memiliki berbagai keterbatasan baik sumber daya manusia maupun anggaran. Oleh karena itu, diperlukan keterlibatan pihak lain, dalam hal ini adalah pihak Swasta atau penanam modal.Pemerintah daerah hanya bertanggung jawab secara lebih penuh dalam bentuk kebijakan dasar yang diperlukan bagi pembangunan daerah, salah satunya berupa kebijakan dasar pengembangan penanaman modal.

Kabupaten Garut memiliki potensi daerah yang sangat banyak dan bervariasi.Kekayaan alamnya meliputi gunung, rimba, laut, pantai, sungai, bahan tambang, tanah yang subur dan panorama yang sangat indah. Potensi ini, jika dikelola dengan baik akan menjadi faktor pendorong yang sangat besar bagi percepatan pembangunan daerah. Oleh karena itu, dalam rangka optimalisasi potensi wilayah sekaligus meningkatkan daya saing Kabupaten Garut diperlukan kajian strategis atas potensi wilayah yang dimiliki Kabupaten Garut berupa kajian sumber daya yang terkait dengan investasi. Hasil kajian ini tentunya akan semakin memperjelas posisi potensi daerah yang dimiliki disamping akan memberikan informasi yang tepat bagi para stakedolder daerah termasuk didalamnya para penanam modal.

Sesuai dengan Peraturan Bupati Nomor 163 Tahun 2013 tentang Perubahan atas Peraturan Bupati Garut Nomor 472 Tahun 2011 tentang Standar Pelayanan Minimal (SPM) Pelayanan Dasar di Lingkungan Pemerintah Daerah Kabupaten Garut hasil kajian sumber daya yang terkait dengan investasi merupakan dokumenkebijakan penanaman modal daerah dalam rangka meyediakan informasi peluang usaha sektor/bidang usaha unggulan. Keberadaan hasil kajian ini dinilai sangat penting untuk meningkatkan daya saing daerah khususnya sebagai bahan promosi investasi dalam rangka meningkatkan investasi daerah.

\section{Perumusan Masalah}


M. Widaningsih, Roadmap Pengembangan Penanaman Modal Wilayah Garut Selatan ...

Permasalahan yang akan menjadi topik perhatian pada kajian ini adalah masalah bidang usaha unggulan berupa potensi dan peluang investasi yang akan ditawarkan kepada investor - Saat ini informasi mengenai bidang usaha unggulan tersebut belum tersedia sesuai dengan kebutuhan. Oleh sebab itu, perlu dilakukan analisis yang komprehensif tentang potensi dan peluang investasi di Kabupaten Garut. Selanjutnya dari peluang investasi tersebut perlu dikaji lebih mendalam melalui penyusunan feasibility study peluang investasi unggulan.

\section{Tujuan}

1. Mengidentifikasi potensi ekonomi berupa komoditas/produk yang ada di Kabupaten Garut.

2. Memilih komoditas/produk tersebut menjadi komoditas unggulan.

3. Menganalisis komoditas unggulan terpilih menjadi potensi/peluang investasi terpilih.

\section{Manfaat kajian ini adalah:}

1. Memperoleh gambaran potensi ekonomi berupa komoditas/produk yang ada di Kabupaten Garut.

2. Memperoleh gambaran produk unggulan dan potensi/peluang investasi terpilih di Kabupaten Garut.

\section{METODE PENELITIAN}

\section{Desain Penelitian}

Desain penelitian yang dipergunakan dalam kajian ini adalah descriptive analysis. Desain ini bertujuan untuk memperoleh gambaran tentang gejala-gejala yang diteliti pada saat sekarang. Dari hasil gambaran tersebut, selanjutnya dicari jawaban bagi pemecahan masalah atau fenomena-fenomena yang ada.

\section{Tempat dan Waktu Penelitian}

Lokasi penelitian adalah Wilayah Garut Selatan, dengan cakupan wilayah meliputi 16 Kecamatan yaitu Cikajang, Banjarwangi, Cisewu, Caringin, Talegong, Bungbulang, Mekarmukti, Pamulihan, Pakenjeng, Cikelet,
Pameungpeuk, Cibalong, Cisompet, Peundeuy, Singajaya dan Cihurip.

Penelitian ini dilakukan selama 4 bulan Tahun 2015

\section{TeknikPengumpulan Data}

1. Wawancara pengumpulan data dengan cara mengajukan pertanyaan serta berkomunikasi langsung dengan pihakpihak tertentu yang berkompeten. Hal ini dilakukan sebagai dasar untuk menentukan tahapan serta pencarian informasi mengenai penyelesaian masalahan sesuai dengan tujuan penelitian yang dilaksanakan.

Dalam rangka mendapatkan gambaran untuk melakukan analisa maka data yang digunakan adalah: yaitu data primer dan data sekunder. Adapun data primer diperoleh dengan cara wawancara mendalam (in-depth interview) terhadap Dinas Perindustrian, Perdagangan, Badan Penanaman Modal, Dinas Pertanian dan Perkebunan, Dinas Perikanan dan Kelautan, Kehutanan, Dinas Pariwisata, Dinas Pertambangan, Bappeda, pelaku usaha, akademisi dan instansi terkait lainnya.

Data sekunder diperoleh dari Dinas Perindustrian dan Perdagangan, Badan Pusat Statistik, Bappeda dan instansi terkait. Seluruh data sekunder merupakan data time series untuk Kabupaten Garut.

2. Studi Dokumen yaitu mempelajari teori, aturan-aturan atau dokumen-dokumen tertulis yang ada kaitannya dengan materi yang dikaji. Sumber pustaka juga dapat digunakan untuk mendukung data objek penelitian sebagai data sekunder penelitian (data BPS atau penyedia data lainnya).

\section{Teknik Analisis Data}

Teknik analisis dilakukan dengan cara deskriptif terhadap arah pengembangan penanaman modal di wilayah Garut Selatan yang ditetapkan berdasarkan potensi /peluang investasi unggulan yang ada, tinjauan terhadap tantangan daerah pada masa sekarang dan yang akan datang serta kesesuaian dengan RUPM RI, RUPM Provinsi Jawa Barat, RPJMD Kab. Garut dan RTRW Kabupaten Garut. 
Pada kajian ini dibutuhkan berbagai analisis untuk mencapai sasaran dan tujuan penelitian. Teknik analisis ini dibuat dengan harapan mampu menjelaskan mengenai hasil penelitian yang berorientasi pada:

1. Penetapan Komoditas unggulan di wilayah Garut Selatan.

2. Penetapan Potensi/peluang investasi di wilayah garut selatan.

3. Penetapan road map pengembangan potensi/peluang investasi Garut Selatan.
Adapun Teknik analisis data yang digunakan adalah :

\section{Teknik AHP}

2. Teknik pemilihan alternatif menggunakan Borda Ranking

\section{Teknis Analisis SWOT}

Adapun indikator yang digunakan dalam melakukan pemetaan potensi investasi dagambarkan sebagai berikut:

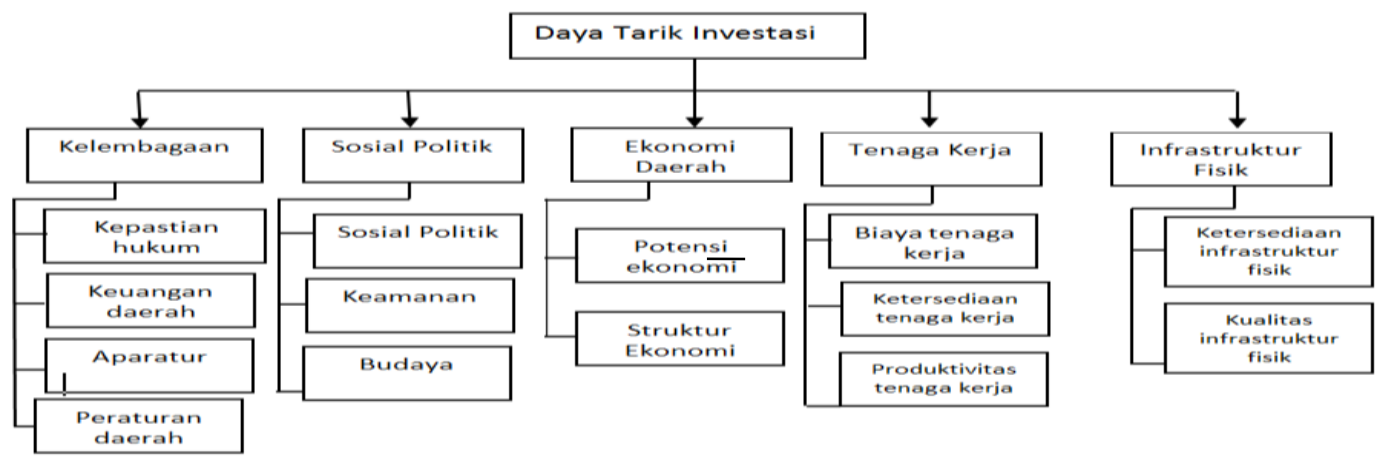

\section{Gambar 1.1 Faktor-faktor Penentu Daya Tarik Investasi di Daerah}

Melalui analisis ini akan tergambar kekuatan dan kelemahan yang dimiliki serta peluang dan ancaman yang dihadapi komoditas unggulan sehingga dapat dipetakan komoditas unggulan yang memiliki potensi innestasi berdasarkan persepsi pelaku usaha. Hasil analisis akan memetakan posisi komoditas unggulan terhadap lingkungannya dan menyediakan pilihan strategi umum yang sesuai, serta dijadikan dasar untuk memilih strategi untuk mencapai sasaran-sasaran yang ditetapkan yang ditetapkan untuk memenuhi kebutuhan dan harapan dari para stakeholders. Adapun hasil Analisis SWOT digunakan sebagai kerangka acuan untuk penetapan road map pengembangan potensi/peluang investasi Garut Selatan

\section{HASIL PENELITIAN DAN PEMBAHASAN}

Investasi adalah penanaman modal untuk satu atau lebih aktiva yang dimiliki dan biasanya berjangka waktu lama dengan harapan mendapatkan keuntungan yang lebih besar di masa-masa yang akan datang. Menurut Husnan (1996: 5) menyatakan bahwa "proyek investasi merupakan suatu rencana untuk menginvestasikan sumber-sumber daya, baik proyek raksasa ataupun proyek kecil untuk memperoleh manfaat pada masa yang akan datang." Pada umumnya manfaat ini dalam bentuk nilai uang. Sedang modal, bisa saja berbentuk bukan uang, misalnya tanah, mesin, bangunan dan lain-lain. Namun baik sisi pengeluaran investasi ataupun manfaat yang diperoleh, semua harus dikonversikan dalam nilai uang.

Suatu rencana investasi perlu dianalisis secara seksama. Analisis rencana investasi pada dasarmya merupakan penelitian tentang dapat tidaknya suatu proyek (baik besar atau kecil) dapat dilaksanakan dengan berhasil, atau suatu metode penjajakkan dari suatu gagasan usaha/bisnis tentang kemungkinan layak atau tidaknya gagasan usaha/bisnis tersebut dilaksanakan. Maka berdasarkan hal tersebut, 
para investor memerlukan data yang akurat mengenai komoditas yang memiliki peluang investasi beserta lokasi sumberdaya alam tersebut. Selain itu para investor membutuhkan data tentang infrastruktur pendukung seperti: jalan, pelabuhan, energy listrik dan sebagainya. Demikian pula dengan hasil-hasil studi kelayakan dari instansi terkait tentang komoditas-komoditas tersebut.

\section{Komoditas Unggulan yang Memiliki Peluang Investasi}

Berdasarkan studi lapangan yang dilakukan oleh peneliti, diperoleh gambaran mengenai kendala yang seringkali dihadapi oleh para petani, di antaranya adalah kesulitan para petani memperoleh kepastian harga jual hasil panennya serta informasi mengenai distributor yang dapat menerima hasil panennya. Disamping itu, informasi yang minim terkait pengolahan hasil panen yang masih belum maksimal terinformasi pada para petani, dimana petani masih melakukan sistem tanam-petikjual. Dimana tentunya bahan mentah tersebut akan memiliki value apabila diolah terlebih dahulu sebelum dijual. Untuk itu peneliti memberikan gambaran mengenai produk turunan hasil panen untuk masing-masing komoditas yang tergambar dalam pohon industri tentunya dapat menjadi kerangka acuan bagi para petani serta industri olahan untuk membuat komoditas unggulan menjadi lebih memiliki nilai jual serta mampu membangkitkan sektor lainnya untuk tumbuh dan berkembang.

\section{Sektor Pertanian}

\section{a. Kacang tanah}

Kacang tanah merupakan tumbuhan yang dapat hidup dalam iklim tropis dan subtropis. Indonesia sebagai Negara beriklim tropis menjadi area yang sangat cocok sebagai tempat tumbuh kacang tanah. Dengan iklim yang mendukung tumbuhnya kacang tanah, Indonesia menjadi salah satu Negara yang menjadi produsen terbesar kacang tanah pada tahun 2010 menurut data FAO dengan menempati urutan ke tujuh. Komoditas kacang tanah mempunyai arti yang strategis karena menyediakan kebutuhan paling esensial bagi kehidupan sebagai bahan pangan serta sumber protein nabati yang sangat dibutuhkan. Kacang tanah banyak digunakan sebagai bahan baku olahan makanan. Selain itu kacang tanah juga diekspor ke luar negeri.

Pengembangan komoditas kacang di Indonesia sebagian besar hanya diolah sebagai bahan makanan. Padahal kacang memiliki kandungan lain yang sangat potensial untuk dikembangkan selain hanya sebagai bahan makanan.

Beberapa kecamatan di Kabupaten Garut berada pada ketinggian di bawah 500 $\mathrm{m}$ di atas permukaan laut dengan suhu tinggi, hal ini sangat cocok untuk ditanami kacang tanah. Berdasarkan data yang disajikan, komoditas kacang tanah terbesar ada di kecamatan Cikelet.Setiap bagian dari kacang tanah dapat dimanfaatkan untuk memenuhi kebutuhan. Mulai dari biji kacang tanah, daun, dan batang kacang tanah dapat dimanfaatkan. Pengolahan kacang tanah dapat dilakukan dalam bidang kuliner, pakan ternak, dan untuk industri pembenihan. Dalam proses pengolahannya, biji kacang tanah dapat diolah menjadi produk setengah jadi sebagai bahan baku dalam pembuatan produk yang lain atau dapat langsung dimanfaatkan dari biji mentah menjadi produk akhir. Pengolahan biji kacang tanah menjadi produk setengah jadi contohnya adalah pembuatan tepung kacang tanah, minyak kacang tanah, mentega, pasta, tahu kacang tanah, susu kacang tanah, dan bungkil kacang tanah. Sedangkan pengolahan biji kacang tanah menjadi produk akhir contohnya adalah pembuatan cookies, selai kacang, permen, kacang oven, kacang sangrai, kacang atom, rempeyek, dan gula kacang. Biji kacang juga dapat dimanfaatkan sebagai campuran minuman seperti wedang ronde, bajigur, dan wedang kacang. Contoh lain dari pemanfaatan biji kacang adalah diolah menjadi beraneka macam bumbu. Batang dan daun kacang tanah dapat dimanfaatkan sebagai pakan ternak. Kacang Tanah memiliki potensi yang tinggi untuk dikembangkan hasil olahannya. Selain dapat 
dimanfaatkan di bidang kuliner, kacang tanah juga bermanfaat dalam bidang kesehatan. Dengan kandungan zat yang bermanfaat bagi kesehatan, kacang tanah memiliki prospek yang bagus untuk pengembangan industri di bidang farmasi. Kacang tanah mengandung fitosterol yang berfungsi untuk mereduksi penyakit kanker atau tumor, mengandung tembaga dan magnesium yang berfungsi untuk mencegah penyakit jantung koroner. Omega-3 dan omega-9 yang terkandung dalam kacang tanah dapat memelihara kerja jantung. Kacang tanah juga mengandung lecithin untuk meeduksi kolesterol darah dan resveratrol, salah satu fitokimia. Penelitian menunjukkan bahwa resveratrol mengurangi resiko stroke dengan mengubah mekanisme molekul pembuluh darah dan menaikkan produksi hormone vasodilator (Astawan 2009). Dengan kandungan zat-zat yang bemanfaat bagi tubuh, kacang tanah dapat diolah menjadi suplemen makanan untuk menjaga kesehatan dan mencegah penyakitpenyakit seperti yang disebut di atas.

\section{b. Kentang}

Sebagian besar sayuran yang dibudidayakan oleh petani di Kabupaten Garut adalah sayuran dataran tinggi yang mempunyai nilai ekonomis cukup tinggi. Beberapa sayuran yang teridentifikasi sebagai komoditas unggulan prioritas pertama adalah kentang Adapun daerah yang potensial untuk pengembangan kentang di Kabupaten Garut adalah adalah Kecamatan Cikajang.

Dalam melakukan budidaya kentang, potensi yang dapat dikembangkan adalah dalam menghasilkan varietas baru salah satunya, bibit kentang jenis Fik-Ri. Varietas ini tidak diragukan lagi keunggulannya karena produksinya yang sangat berlimpah, yakni mencapai 35 ton per hektar, atau lebih tinggi 10 ton di atas produk nasional yang hanya mencapai 25 ton per hektar.

\section{Sektor Perkebunan (Karet)}

Pengembangan perkebunan secara menyeluruh telah memberikan dukungan terhadap upaya peningkatan perekonomian daerah dan dapat mempercepat pencapaian misi Kabupaten Garut sebagai daerah agribisnis dan agroindustri.

\section{a. Karet}

Karet merupakan salah satu komoditi perkebunan penting, baik sebagai sumber pendapatan, kesempatan kerja dan devisa, pendorong pertumbuhan ekonomi sentrasentra baru di wilayah sekitar perkebunan karet maupun pelestarian lingkungan dan sumber daya hayati.

Kondisi agribisnis karet saat ini menunjukkan bahwa karet dikelola oleh rakyat, perkebunan negara dan perkebunan swasta. Di tingkat hilir, jumlah pabrik pengolahan karet sudah cukup, namun selama lima tahun mendatang diperkirakan akan diperlukan investasi baru dalam industri pengolahan, baik untuk menghasilkan crumb rubber maupun produk-produk karet lainnya karena produksi bahan baku karet akan meningkat. Kayu karet sebenarnya mempunyai potensi untuk dimanfaatkan sebagai bahan pembuatan furniture tetapi belum optimal, sehingga diperlukan upaya pemanfaatan lebih lanjut.

Agribisnis karet alam di masa datang akan mempunyai prospek yang makin cerah karena adanya kesadaran akan kelestarian lingkungan dan sumberdaya alam, kecenderungan penggunaan green tyres, meningkatnya industri polimer pengguna karet serta makin langka sumber-sumber minyak bumi dan makin mahalnya harga minyak bumi sebagai bahan pembuatan karet sintetis. Kayu karet juga akan mempunyai prospek yang baik sebagai sumber kayu menggantikan sumber kayu asal hutan. Untuk lebih jelasnya, pemanfaatan tanaman karet disajikan pada gambar pohon industri karet berikut ini: 
M. Widaningsih, Roadmap Pengembangan Penanaman Modal Wilayah Garut Selatan ...

POHON INDUSTRI KARET

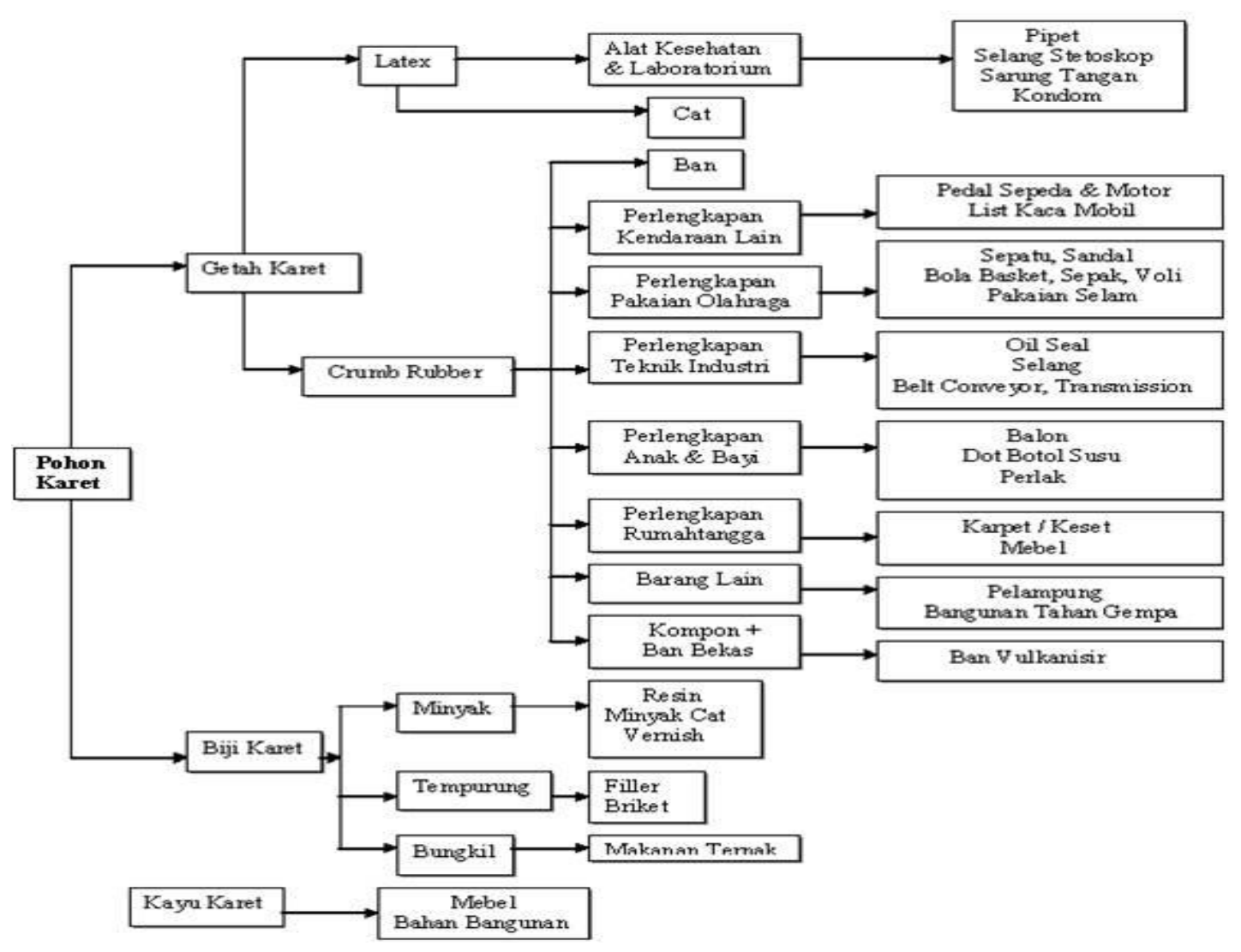

Gambar 1.2

Pohon Industri Karet

Dari gambar di atas, maka manfaat pohon karet sebagai berikut: (1) Getah (latex) nya digunakan untuk berbagai produk jadi untuk keperluan rumah tangga seperti ember, mebel, keset, matras, mainan anak, benang karet; untuk keperluan industri seperti otomotif, sepatu, tas, garment, selang, conveyor belt, alat kesehatan dan olahraga, dsb; (2) Batang (kayu) nya dapat dibuat mebel dan merupakan bahan bakar kamar asap pabrik RSS karena kandungan flavonoid yang ada dalam asapnya bermanfaat sebagai anti jamur pada blanket / lembaran sit; (3) Areal kebun karet berfungsi sebagai penangkap polutan di udara (dapat mengurangi pencemaran udara).

Selanjutnya mengenai potensi pengembangan komoditas karet di Kabupaten Garut dapat dilihat pada tabel berikut ini:

\section{Sektor Peternakan (Sapi Potong)}

Daging merupakan salah satu bahan pangan yang sangat penting dalam mencukupi kebutuhan gizi masyarakat, serta merupakan komoditas ekonomi yang mempunyai nilai sangat strategis. Untuk memenuhi kebutuhan daging di Indonesia saat ini berasal dari (1) unggas (broiler, petelur jantan, ayam kampong dan itik ), (2) sapi (sapi potong, sapi perah dan kerbau), (3) babi, serta (4) kambing dan domba (kado). Dari keempat jenis daging tersebut, hanya konsumsi daging sapi $(<2$ $\mathrm{kg} / \mathrm{kapita} /$ tahun) yang masih belum dapat dipenuhi dari pasokan dalam negeri, karena laju peningkatan permintaan tidak dapat diimbangi oleh pertambahan populasi.

Untuk meningkatkan kualitas dan kuantitas daging sapi potong di dalam negeri, baik yang berasal dari sapi potong impor maupun sapi potong lokal, telah banyak berkembang akhir-akhir ini berbagai usaha penggemukan sapi potong yang dilakukan oleh para feed looters ataupun 
para peternak kecil di Indonesia. Bagi peternak kecil, yang kebanyakan adalah petani di desa-desa, usaha penggemukan sapi ini merupakan alternatif yang bisa di lakukan untuk menambah pendapatan keluarga. Dengan penggemukan selama 2 sampai 6 bulan, akan dapat diperoleh hasil berupa nilai tambah berat badan sapi potong dengan kualitas daging yang lebih baik.

Kegiatan penggemukan sapi ini bisa dilakukan oleh sejumlah peternak kecil secara bersama-sama di dalam koordinasi KUD dengan mengadakan kerjasama kemitraan secara terpadu dengan Pengusaha Peternakan Besar (feed looters) yang memiliki kegiatan impor sapi bakalan atau pedagang sapi lokal dan pemasaran sapi hasil penggemukan yang dilakukannya. Untuk itu sebagai anggota KUD mereka bekerjasama dengan Perusahaan Peternakan Besar menggunakan kredit perbankan untuk modal investasi dan modal kerjanya dalam suatu Proyek Kemitraan Terpadu (PKT) Penggemukan Sapi. Dengan makin berkembangnya jumlah kegiatan penggemukan sapi yang dilakukan oleh para peternak kecil dalam Proyek Kemitraan Terpadu ini, maka makin banyak pula permintaan kredit yang diajukan kepada perbankan untuk keperluan usaha penggemukan sapi. Kredit yang dimintakan adalah KUK atau KKPA yang memiliki tingkat bunga relatif murah. Salah satu model kelayakan PKT ialah PKT Penggemukan Sapi, untuk dipergunakan sebagai bahan acuan bagi pihak-pihak yang berkepentingan, khususnya pihak perbankan di dalam mengadakan evaluasi terhadap adanya permintaan kredit sejenis sehingga dapat menunjang pengembangan usaha dalam sub sektor peternakan.

Prospek industri sapi di Indonesia cukup menjanjikan. Oleh sebab itu, Arah pengembangan ternak sapi melalui peningkatan populasi ternak dapat dilakukan melalui beberapa cara, antara lain: (1) mempercepat umur beranak pertama, dari > 4,5 tahun menjadi $<$ 3,5 tahun, (2) memperpendek jarak beranak dari $>18$ bulan menjadi sekitar $12-14$ bulan sehingga akan ada tambahan jumlah anak selama masa produksi sekitar 2 ekor/induk, (3) menekan angka kematian anak dan induk, (4) mengurangi pemotongan ternak produktif dan ternak kecil/muda, (5) mendorong perkembangan usaha pembibitan penghasil sapi bibit, serta (6) menambah populasi ternak produktif, melalui impor sapi betina produktif.

Pada industri hulu, arah pengembangan industri hulu ini difokuskan untuk membuat pola integrasi yang berdampak pada pengurangan biaya pakan usaha cow calf operation secara signifikan, sehingga produk yang dihasilkan mempunyai daya saing yang sangat tinggi. Namun untuk usaha penggemukan diperlukan dukungan khusus berupa ransum rasional yang berkualitas namun tetap murah. Dalam hal ini yang terpenting adalah biaya ransum untuk meningkatkan pertambahan bobot badan masih ekonomis. Usaha agribisnis hulu lain yang perlu dikembangkan adalah penyediaan calon-calon induk; dan pejantan unggul, baik untuk keperluan IB maupun pejantan untuk kawin alam.

Industri hilir yang dapat dikembangkan untuk menunjang usaha sapi potong pada diagram pohon industri agribisnis sapi potong adalah pengolahan bahan mentah utama yang akan dihasilkan seperti daging, susu dan kulit. Fasilitas utama dan pertama yang diperlukan adalah Rumah Potong Hewan (RPH) dan tempat penyimpanan produk yang memadai.

Sapi potong, selain sebagai penghasil daging, juga memberikan kontribusi besar bagi penyedia tenaga kerja di sawah bersama dengan ternak kerbau, khususnya sawah dengan kontur berbukit yang tidak mungkin diolah menggunakan traktor. Fungsi ganda dari kerbau dan sapi potong menjadi alasan mengapa petani menganggap penting untuk memelihara ternak ini. Daerah dengan konsentrasi ternak sapi potong yang tinggi adalah Kecamatan Pameungpeuk. Penyebaran sapi potong secara geografis menyebar terkonsentrasi di wilayah selatan, khususnya Kecamatan Pameungpeuk, Cikelet, Cibalong, Cisompet dan Bungbulang. Adapun jumlah populasi ternak sapi di Kabupaten Garut tersebar diseluruh 
M. Widaningsih, Roadmap Pengembangan Penanaman Modal Wilayah Garut Selatan ...

kecamatan dengan populasi terbesar ada di kecamatan Cibalong yaitu 3.051 ekor.

\section{Sektor Perikanan}

Perikanan laut adalah salah satu sub sektor ekonomi yang sangat potensial untuk dikembangkan. Pantai selatan Kabupaten Garut memiliki potensi berupa Zona Ekonomi Eksklusif (ZEE) 200 mil laut dengan luas areal penangkapan 28. $560 \mathrm{~km} 2$ dan diestimasi memiliki potensi lestari (MSY) sebesar 166.667 ton/tahun.

Berikut ini disajikan komoditas unggulan dari sektor perikanan:

\section{a. Tambak Udang}

Budidaya udang tambak merupakan prospek yang cukup bagus untuk dikembangkan dipantai selatan Garut, hal ini didukung oleh kondisi perairan yang belum tercemar bila dibandingkan dengan perairan pantai utara Jawa. Kegiatan perikanan laut nampaknya perlu mendapat perhatian dalam rangka meningkatkan tingkat pemanfaatan dari potensi lestari ikan laut di Kabupaten Garut. Berbagai upaya yang dapat dilakukan untuk memanfaatkan potensi perikanan laut yang cukup besar ini adalah dengan pemberdayaan nelayan, peningkatan sarana dan prasarana, bantuan modal dan bimbingan. Serta penetapan kawasan pantai Garut Selatan sebagai daerah pengembangan agribisnis berbasis usaha perikanan.

Perikanan Tambak diarahkan pengembangannya di wilayah Kecamatan Cibalong, Pameungpeuk, Cikelet, Pakenjeng, Bungbulang, dan Caringin seluas 28,50 ha. Dengan jumlah produksi 420 ton. Potensi pengembangan pertambakan intensif adalah dengan mengembangkan sistem tambak udang plastik (biokrit), karena struktur kawasan pesisir Garut yang sebagian besar berpasir.

Lokasi yang cocok untuk tambak udang yaitu pada daerah pantai yang mempunyai tanah bertekstur liat atau liat berpasir yang mudah dipadatkan sehingga mampu menahan air dan tidak mudah pecah.

\section{b. Perikanan Tangkap}

Secara ekosistem, potensi wilayah pesisir Kabupaten Garut terdiri dari komponen ekosistem pesisir utama yaitu: (1) Estuari seluas 24 hektar; (2) ekosistem mangrove seluas 50,9 hektar; (3) ekosistem lamun seluas 75 hektar; dan (4) ekosistem terumbu karang seluas 525 hektar.

Potensi sumberdaya perikanan meliputi luas areal penangkapan sebesar \pm 28.560 $\mathrm{km} 2$ dan diestimasi memiliki potensi lestari (MSY) sebesar 166.667 ton/tahun. Sementara untuk zona teritorial (12 mil laut) memiliki potensi sebesar 10.000 ton/tahun. Sampai saat ini nelayan Kabupaten Garut baru memanfaatkan zona territorial dengan hasil tangkapan mencapai 4.994,16 ton (atau sekitar 49,94\% dari potensi yang ada). Hal ini disebabkan karena armada penangkapan yang dimiliki saat ini baru berupa perahu/kapal ukuran kecil (5-10 GT). Sumberdaya ikan yang umumnya ditangkap di perairan selatan Kabupaten Garut diantaranya adalah tuna, tongkol, cakalang, cumi-cumi, layur, kakap, bawal hitam, kerapu, baronang, cucut botol, lobster, dan ikan hias. Disamping ikan-ikan tersebut juga terdapat potensi rumput laut yang cukup besar. Selain itu, terdapat potensi tambak di sepanjang garis pantai yaitu sekitar 1.000 ha. Selain perikanan tangkap, Kabupaten Garut juga memiliki potensi budidaya perikanan antara lain yaitu (1) budidaya laut dengan potensi sebesar 3.400 ha; dan budidaya tambak dengan potensi sebesar 1.000 ha dan baru dimanfaatkan sekitar 26,6 ha $(2,66 \%)$.

Komoditas unggulan prioritas kedua perikanan laut didominasi oleh ikan layur, kemudian diikuti oleh ikan tongkol dan kakap yang merupakan hasil tangkapan dengan alat pancing dan jaring. Produksi ikan dari Kabupaten Garut sebagian besar untuk memenuhi kebutuhan masyarakat Garut. Tingginya jumlah ikan segar yang masuk Kabupaten Garut merupakan tantangan dan peluang pasar dalam hal peningkatan produksi ikan di Kabupaten Garut. Pengembangan komoditas perikanan darat dapat ditempuh melalui usaha 
penerapan teknologi tepat guna. Pemanfaatan sawah untuk areal mina padi perlu terus ditingkatkan. Begitu juga dengan pemanfaatan perairan umum, baik melalui usaha budidaya ikan dengan sistem karamba, karamba jaring apung, sistem pagar atau hampang merupakan alternatif yang dapat dikembangkan mengingat Kabupaten Garut mempunyai potensi kolam dan sungai yang cukup besar. Komoditas yang bisa dikembangkan dengan sistem ini adalah ikan mas, nilem dan nila. Tampaknya pengembangan budidaya ikan dengan kolam air deras untuk memelihara ikan mas, akan tersisih oleh sistem budidaya dengan karamba jaring apung, karena selain keunggulan pertumbuhannya juga biaya produksinya yang relatif lebih rendah. Kegiatan restocking di perairan umum perlu terus ditingkatkan dengan melibatkan masyarakat sekitar situ (kolam) atau sungai sebagai pengelola dan pengawas, sehingga dapat diatur musim penangkapannya, dan alat yang boleh dioperasikan.

Untuk itu, dalam upaya peningkatan produksi ikan laut dilakukan melalui bantuan sarana prasarana dan permodalan kelompok nelayan, pengembangan usaha perikanan, Pengembangan tata kelembagaan perikanan serta Peningkatan teknologi dan armada tangkap.

\section{Sektor Kehutanan}

Potensi Garut selatan sesuai dengan karakteristi kwilayahnya masih didominasi oleh sekor pertanian (tanamanpangan, perkebunan, peternakan, perikanandan kehutanan, dimana berdaarkan analisis penggunaan lahan di Kabupaten Garut didominasi oleh kegiatan kehutanan. Berikut ini disajikan salah satu hasil hutan bukan kayu yang ada di Kabupaten Garut yang memiliki potensi investasi:

Sutera alam merupakan salah satu hasil hutan non kayu yang bernilai ekonomi tinggi, disamping pasarnya yang luas mencakup pasar di dalam dan di luar negeri, permintaannya juga relatif tidak terpengaruh oleh perubahan situasi ekonomi karena konsumennya adalah golongan menengah keatas.

Pengembangan persuteraan alam yang merupakan kegiatan agroindustri yang meliputi pembibitan ulat sutera, budidaya tanaman murbei, pemeliharaan ulat sutera, pemintalan benang, pertenunan, pembatikan/pencelupan, garmen dan pembuatan barang jadi lain termasuk pemasarannya.

Sutera alam merupakan salah satu produk yang potensial untuk dikembangkan di Kabupaten Garut, sampai saat ini lahan murbei yang telah dikembangkan sebesar 13 Ha. Ada beberapa faktor yang melatarbelakangi hal tersebut, yaitu: (1) faktor ketersediaan lahan dan kondisi agroklimat sangat mendukung, (2) terdapat stasiun persutraan alam di Bayongbong yang mendukung pengembangan sutera alam di Jawa Barat, (3) terdapat kampung tenun sutera di Panawuan, (4) dapat mendorong ekonomi kreatif, (5) kabupaten Garut akan dijadikan pengembangan sentra HHBK unggulan sutera alam. (6) beberapa negara pengekspor utama benang sutera (Jepang dan Korea Selatan) mengalami krisis efisiensi karena kelangkaan lahan dan upah tenaga kerja tinggi, (7) penawaran komoditas benang sutera pada pasar internasional relatif rendah dibanding serat tekstil lain, (8) permintaan benang sutera terus meningkat sejalan dengan peningkatan pendapatan, perkembangan dunia mode, diversifikasi produk berbahan baku sutera, dan (9) kebutuhan benang sutera Indonesia sebagaian besar dipenuhi melalui impor.

\section{Sektor Pariwisata}

Berdasarkan RTRWN dan RTRW provinsi Jawa barat, peran Kabupaten Garut terkait dengan kebijakan struktur ruang wilayah Jawa Barat yang menetapkan dua kategori wilayah, yaitu wilayah utama dan wilayah penunjang, dalam hal ini Kabupaten Garut sebagai wilayah penunjang yang mendukung pertumbuhan ekonomi di wilayah utama. Dalam rencana pemanfaatan 
M. Widaningsih, Roadmap Pengembangan Penanaman Modal Wilayah Garut Selatan ...

ruang RTRW provinsi yang menunjukkan alokasi untuk kegiatan pertanian lahan kering, hutan produksi, perkebunan dan perikanan.

Dalam kebijakan pembangunan Kabupaten Garut, struktur ruang wilayah Kabupaten Garut dibagi menjadi 3 pusat pertumbuhan, Yaitu:

a. Pusat pertumbuhan Garut Utara, merupakan pusat industri pengolahan hasil pertanian dan perkebunan.

b. Pusat pertumbuhan Garut Tengah, sebagai pusat pemerintahan, perdagangan dan jasa, pendidikan dan industri pengolahan hasil pertanian.

c. Pusat pertumbuhan Garut Selatan, sebagai pusat pengembangan pariwisata dan konservasi (yaitu Pameungpeuk dan Bungbulang).

Maka berdasarkan hal tersebut, sektor pariwisata memiliki peluang investasi yang cukup besar di Kabupaten Garut.

Dalam rangka upaya pengembangan wilayah yang lebih merata, peranan pariwisata menjadi sangat penting, mengingat panjangnya mata rantai kegiatan usaha kepariwisataan. Kegiatan-kegiatan yang dimaksud meliputi: biro perjalanan, pengangkutan, perhotelan, restoran pemandu wisata/pramuwisata, kerajinan rakyat, kesenian daerah, pemeliharan dan pengembangan obyek wisata. Rantai kegiatan pariwisata ini jelas akan membutuhkan hasil-hasil pertanian, peternakan, perikanan, kerajinan cinderamata, bahan dan alat bangunan. Dengan demikian pengembangan sektor pariwisata dapat menggerakkan sektorsektor ekonomi lainnya atau dengan kata lain sektor ini mempunyai imbas secara multisektoral.

Permasalahan pengembangan pariwisata yang dihadapi, meliputi:

a. Belum memadainya sarana komunikasi dan pemasaran produk wisata.

b. Belum optimalnya peran serta para pengusaha/swasta dalam mendukung kegiatan kepariwisataan. c. Masih terpusatnya kegiatan wisata pada lokasi-lokasi wisata tertentu.

d. Masih kurangnya rambu-rambu petunjuk jalan ke arah obyek-obyek wisata potensial.

e. Belum memadainya sarana infrastruktur untuk mendukung pengembangan obyek wisata potensial.

f. Masih kurangnya mutu pelayanan dan atraksi wisata bagi para wisatawan.

g. Pengelolaan beberapa Kawasan Wisata belum tertangani secara komprehensif dan berkelanjutan.

Adapun salah satu potensi pariwisata di Kabupaten Garut yang memiliki peluang investasi adalah sebagai berikut:

\section{Pantai Rancabuaya}

Pantai Rancabuaya memiliki ketinggian 0-200 $\mathrm{m}$ di atas permukaan laut, curah hujan sebesar $1.200 \mathrm{~mm} /$ tahun dengan penyinaran matahari yang sedang dan kekuatan tiupan angin kecil. Perairan pantai berwarna biru, bau air normal, dan temperatur normal. Tinggi gelombang rata-rata kurang dari 1 meter, dan material dasar laut berupa pasir halus, batu karang, dan pasir kasar termasuk daerah sepanjang garis pantai. Kemiringan laut landai, serta ditumbuhi rumput laut dan gang gang hijau sebagai flora laut dominan. Sedangkan fauna laut dominannya adalah ikan tuna dan ikan karang.

Daerah pesisir pantai yang landai ini memiliki material berupa pasir halus putih bersih, dengan panjang 1.000-2.000 dan lebar 100-200 m, serta tingkat abrasi yang kecil, sehingga stabilitas pantainya cukup baik. Flora dominan yang berada di tepi pantai adalah pohon kelapa dan pohon ketapang. Pantai Rancabuaya memiliki kualitas lingkungan dan kebersihan yang baik, dan hampir tidak terdapat berbagai bentuk pencemaran. Pantai ini memiliki visabilitas bebas dengan tingkat kebisingan yang rendah.

Secara administratif, di sebelah utara Rancabuaya berbatasan dengan Desa Caringin, di sebelah barat dengan Samudra Hindia, sebelah selatan dengan 
Desa Indralayang, dan di sebelah timu, berbatasan dengan Desa Sinarjaya. Seeara alamiah, lingkungan alam yang menjadi batas pantai ini adalah lahan pertanian dan perkebunan di sebelah utara, Samudra Indonesia di sebelah barat dan timur, dan lahan pertanian di sebelah selatan. Pantai Rancabuaya yang terletak di desa Purbayani Kecamatan Caringin ini memiliki luas 10 ha dengan luas kawasan keseluruhan sebesar 1.524 ha. Ada 2 sifat kegiatan pariwisata yang dapat dilakukan oleh para wisatawan yang berkunjung ke objek wisata ini, yaitu yang bersifat aktif hiking dan tracking serta yang bersifat pasif, yaitu menikmati pemandangan.

Status kepemilikan lahan area pantai Rancabuaya adalah $70 \%$ tanah milik dan sisanya adalah tanah desa, sedangkan pengelolaannya dilakukan oleh Kompepar (Kelompok penggerak pariwisata) yang anggotanya terdiri dari masyarakat setempat.

Alat tranportasi yang dapat digunakan untuk menuju ke pantai In. adalah 3 buah minibus (bus 3/4) trayek Rancabuaya-Garut yang frekuensinya terjadwal dan beroperasi antara pukul 04.30-08.00. Untuk transportasi ke kawasan, dapat juga mempergunakan angkot yang tidak terjadwal atau mempergunakan kendaraan angkutan desa yang disebut "paranggong" berupa mobil bak terbuka. Jarak kawasan Rancabuaya dari Ibu kota Provinsi Jawa Sarat 167 km, dan jarak dari Ibu kota Kabupaten $105 \mathrm{~km}$, dan jarak dari pusat pembantu Kecamatan (Caringin) $30 \mathrm{~km}$. Akses menuju Pantai Rancabuaya berupa jalan raya kecamatan dengan lebar $6 \mathrm{~m}$ dan panjang $120 \mathrm{~km}$, sedangkan akses di dalam kawasan atau menuju area pantai berupa jalan selebar $4 \mathrm{~m}$ dengan kondisi cukup baik.

\section{Sektor Pertambangan dan Energi}

Potensi pertambangan di Kabupaten Garut sangat besar misalnya emas, biji besi, pasir besi, tembaga, gas bumi dan lain-lan.
Namun sampai saat ini masih dalam proses eksplorasi sehingga belum menghasilkan produksi. Disamping itu apabila mengacu pada Undang-Undang No 12 Tahun 2014 bahwa perijinan untuk pertambangan dan energi ada di kewenangan pusat dimana daerah hanya mempromosikan saja bahwa ini layak untuk investasi.

\section{Penutup}

Dari hasil penyusunan Roadmap Pengembangan Penanaman Modal Wilayah Garut Selatan diharapkan dapat dijadikan landasan penentuan potensi investasi hingga tahun 2025. Kegiatan tersebut pada akhirnya tidak boleh terlepas dari arah kebijakan dan strategi yang ditetapkan dalam RPJMD Kabupaten Garut. Di samping itu dengan tersedianya informasi Peta Panduan (Road Map) dari penanaman modal maka akan semakin memperjelas tahapan fokus kegiatan yang akan dijadikan sasaran secara jangka pendek, jangka menengah, dan jangka panjang.

\section{Daftar Pustaka}

Achmadi, J. 2010. Evaluasi Potensi dan Program Pemerintah dalam Pembangunan Peternakan di Jawa Tengah : Penyediaan Pakan guna Mendukung Swasembada Produk Ternak. Disampaikan pada Pertemuan Evaluasi Pembangunan Peternakan Provinsi Jawa Tengah Tahun 2010, Dinas Peternakan dan Kesehatan Hewan Provinsi Jawa Tengah, tanggal 9-11 Desember 2010.

Basir, H. J., 1990. Penggunaan Limbah Pertanian sebagai Pakan Ternak. Laporan Penelitian Jurusan Peternakan, Fakultas Peternakan Universitas Syiah Kuala Darussalam, Banda Aceh.

Blakely, J. dan D.H. Bade, 1998. Ilmu Peternakan. Edisi 4, Yogyakarta: UGM Press

Budiono, 1990. Ekonomi Mikro. Seri Sinopsis Pengantar Ilmu Ekonomi No. 1.

Edisi kedua, Cetakan ke II. BPFE, Yogyakarta. 
M. Widaningsih, Roadmap Pengembangan Penanaman Modal Wilayah Garut Selatan ...

Ibrahim, Y, H. M., 2003. Studi Kelayakan Bisnis. Edisi Revisi, Jakarta: Penerbit PT. Rineka Cipata.

Kadariah, 1987. Pengantar Evaluasi Proyek, Jakarta: Lembaga Penelitian Fakultas Ekonomi Universitas Indonesia.

Kadarsan, H., 1995. Keuangan Pertanian dan Pembiayaan Perusahaan Agribisnis. Cetakan kedua, Jakarta: PT. Gramedia.
Kariyasa, I. K. 2003. Keterkaitan Pasar Jagung, Pakan dan Daging Ayam Ras di Indonesia. Tesis Magister Sains, Bogor: Program Pascasrjana. Institut Pertanian Bogor.

Kartadisastra, H.R., 1997. Penyediaan dan Pengelolaan Pakan ternak Ruminansia (Sapi, Kerbau, Domba, Kambing). Yogyakarta: Kanisius.

Kasmir dan Jakfar, 2003. Studi Kelayakan Bisnis, Bogor: Kencana. 